\title{
METHODS FOR REDUCING THE ENVIRONMENTAL IMPACT OF ROCK MASS EXCAVATION
}

\author{
Jasmin Jug ${ }^{1^{*}}$, Kristijan Grabar ${ }^{2}$ \\ ${ }^{1}$ University of Zagreb, Faculty of Geotechnical Engineering, Hallerova aleja 7, 42000 Varazdin, Croatia \\ ${ }^{2}$ SPP d.o.o., Trstenjakova 3, 42000 Varazdin, Croatia \\ *E-mail of corresponding author: jasmin.jug@gfv.unizg.hr
}

\begin{abstract}
Many engineering projects and interventions have negative effects on the environment. Rock excavation in civil engineering, either in mining or in construction, often is unthinkable without the use of explosive. However, blasting can have extensive adverse environmental impacts, like vibrations, noise, dust and chemical contamination. Therefore, it is better to avoid blasting activities near urban areas, protected animal habitats, sensitive historic buildings, water protection zones, pipelines, etc. While mechanical excavation is often longer lasting and more expensive, in some cases it may adequately replace blasting, where the applicability of mechanical excavation methods greatly dependent on the rock mass characteristics which should excavate. This paper provides practical examples of using existing methods for the assessment of the applicability of excavation technologies. In order to minimize the project impact on the environment, mechanical excavation was applied in some cases. In one case, the blasting could not be avoided, but controlled careful blasting techniques were applied.
\end{abstract}

Keywords: adverse blasting effects, environment, excavation assessment methods, mechanical excavation, careful blasting.

\begin{tabular}{c}
\hline $\begin{array}{c}\text { Received: } 17.01 .2020 . / \text { Accepted: 03.02.2020. } \\
\text { Published online: } 10.07 .2020 .\end{array}$ \\
Original scientific paper \\
https://oi.org/10.37023/ee.7.1.4
\end{tabular}

\section{INTRODUCTION}

During rock blasting, a chemical reaction takes place, which converts the chemical energy of the explosive into the shock energy and gas energy (Dhekne 2015). Most of the released energy is useful for fragmentation, displacement and movement of broken rock. Wasteful part of energy causes many adverse impacts such as ground vibrations, airblast, fly-rock and dust. Ground vibrations, in other words seismic waves, creates cracks in the surrounding rocks near the blast site and travels at different rates through soil, rocks and water until the energy of the vibration is dissipated. Along their way, blast vibration waves (Figure 1) shake humans, animals, plants and any man-made and other natural's installations. The ground vibration parameters, crucial for the safety of constructions, have a significant correlation with charge weight and distance of blasting. The properties of the vibration medium also impact on the value of vibration parameters (Tomberg \& Toomik 1999).

The environmental effects air blast or noise and dust vary depending on the size and location of the blast field, but also on atmospheric conditions such as wind and humidity. Dust generated by blasting and suspended into the atmosphere greatly affects air quality. The noise is the result of air-overpressure. Changes in air pressure can physically damage glasses on buildings, trees in the surrounding forests and blasting noises can also impair quality of life for humans and animals (Mesec et al. 2018). The fly-rock or particular rock that flies beyond the blast site, causing damage to property, injuries to people and can lead to the fatalities.

The last factor is most important for the safety of aquifers in the vicinity of blasting area. If commercials explosives are spilt on the ground or left undetonated at a blast site, ammonium and nitrate can reach into ground, surface and groundwater.

An appropriate blast design can help in reducing the environmental impacts of blasting, but in some cases it is better to apply mechanical excavation, which includes the following methods: a) digging when easy/very easy excavation conditions exist, b) ripping for moderate to difficult excavation conditions, and c) breaking when the main purpose of the excavation work is to break rock into smaller fragments by using a hydraulic hammer. Digging is very acceptable in construction and mining, especially hydraulic shovel excavators, which are very versatile machines. Solid rock can be excavated by ripping, but the blasting method is more widely used because ripping is often more expensive. The effects of vibration, noise and dust when using digging and ripping technologies are minimal, and there is no danger to human lives, property and slope stability. The operation of the hydraulic hammer has the adverse effects of vibration and noise, but the level of adverse effects is far below the level of blasting effects.

For the assessment appropriate excavatability method, previous studies proposed different classifications. However, there is no generally accepted method, so many different methods are often combined in researches. In this research, some of the most commonly used are tested on several studied sites. 


\section{METHODS FOR EXCAVATION ASSESSMENT}

The methods that are available to predict the rock mass excavatability can be categorised into three classes of methods: an assessment based on seismic velocity, graphical method and grading method. Franklin et al. (1971) presented one of the first graphic methods, based on the correlation between the uniaxial compressive strength of intact rock and the spacing of discontinuities in the rock mass. Weaver (1975) designed the first grading system, taking into account the following features of the rock mass: seismic P-waves velocity, hardness, weathering and spacing, persistence, orientation and separation of discontinuities. However, one of the first developed models for excavation assessment was proposed by Caterpillar Inc. in the late 1950s (Church 1981). This model predicts rock mass ripability primarily based on a seismic velocity of longitudinal P-waves in the rock mass for different rock types, and the assessment procedure was later updated along with the company's latest bulldozers (Caterpillar 2015). There are in the mining profession highly recognized methods for the excavation assessment. For ease of use, three methods were selected.

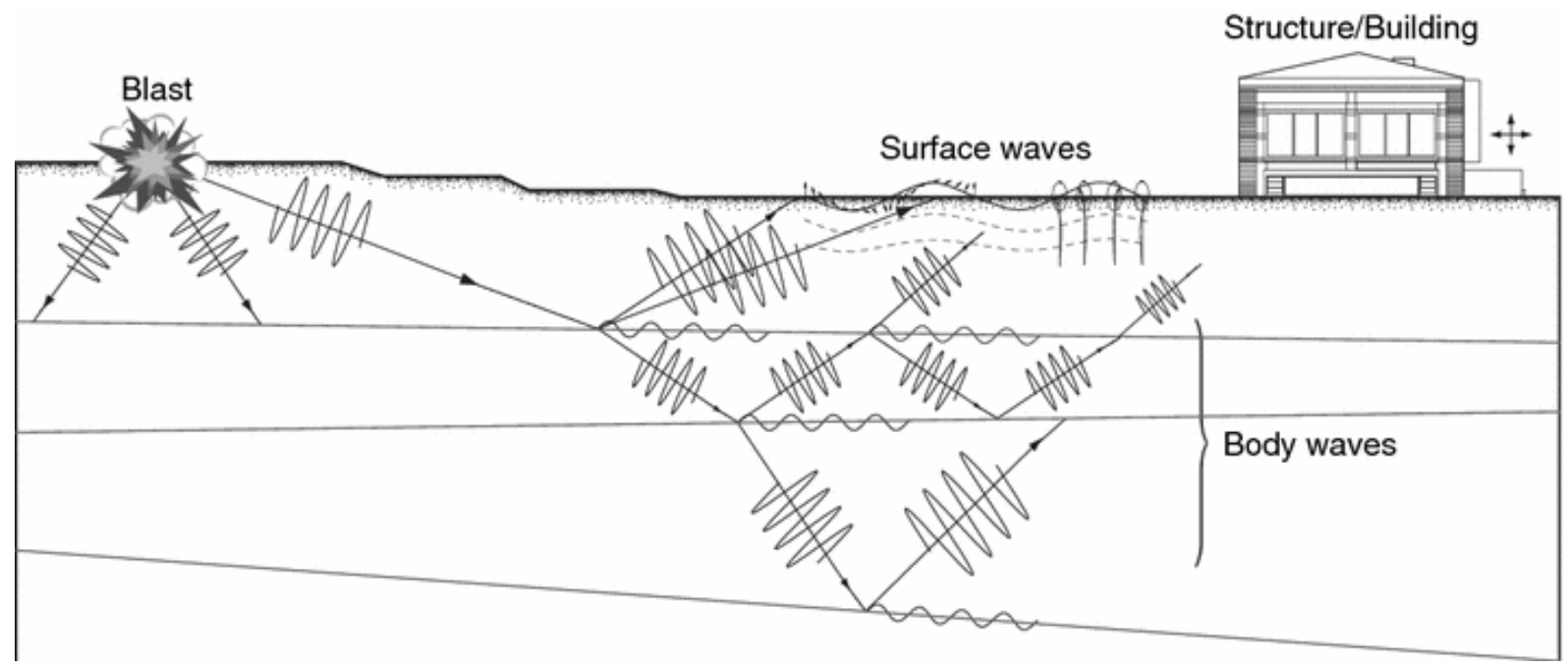

Figure 1. Types of blast vibration waves (Ainalis et al. 2017)

\subsection{Pettifer \& Fokes Method}

One of the most recent assessments on rock mass excavatability was proposed by Pettifer \& Fookes (1994). The chart for excavation assessing (Figure 2) is based on discontinuity spacing and Point load test index (PLTi). Various problems arise when attempting to describe block size in terms of a single dimension, but this is necessary in order to represent average discontinuity spacing simply. The fracture spacing index $\left(\mathrm{I}_{\mathrm{f}}\right)$, which expresses discontinuity spacing, can be customarily determined from measurements along two orthogonal or randomly orientated scanlines, or along a section of drill core. PLTi is the result of Point Load Test (PLT), also known as the Franklin test (Broch \& Franklin 1972).

\subsection{Hoek \& Karzulovic Method}

Hoek and Karzulovic (2000) proposed GSI value ranges for different excavation methods. Figure 3 presents a plot of 23 case histories of excavation by digging, ripping and blasting published by Abdullatif \& Cruden (1983). Geological Strength Index (GSI), proposed by Hoek et al. (1998), is an easy qualitative tool for the quick assessment of rock mass properties. So, Hoek and Karzulovic concluded that rock mass can be dug by an excavator if the GSI $<40$ and rock mass strength $\left(\sigma_{\mathrm{cm}}\right)$ is less than $1 \mathrm{MPa}$, and that ripping is possible in rock masses with the GSI value in the range of 40 to 60 and $\sigma_{\mathrm{cm}}$ strength of up to $10 \mathrm{MPa}$. However, if the rock mass has a value of GSI $>60$ and the strength $>15 \mathrm{MPa}$, the only applicable excavation method is blasting.

\subsection{Tsiambos \& Saroglou Method}

Tsiambaos \& Saroglou (2010) proposed a rock mass classification method with respect to the ease of excavation, based on GSI and PLTi normalized for cylindrical specimens that are $50 \mathrm{~mm}$ in diameter (Is 50 ). As a result of their research, two classification GSI diagrams were proposed, the first for rock masses with Is $5_{0}$ values below $3 \mathrm{MPa}$ (Figure 4) and the second for rock masses with Is $5_{50} \geq 3 \mathrm{MPa}$ (Figure 5). It was found that blasting is required when GSI values are greater than 60 . Successful ripping is generally achieved for rock masses with 
GSI values between 20 and 45. In the transitional zone between the ripping and blasting areas of the GSI charts, excavation with hydraulic breakers is necessary.
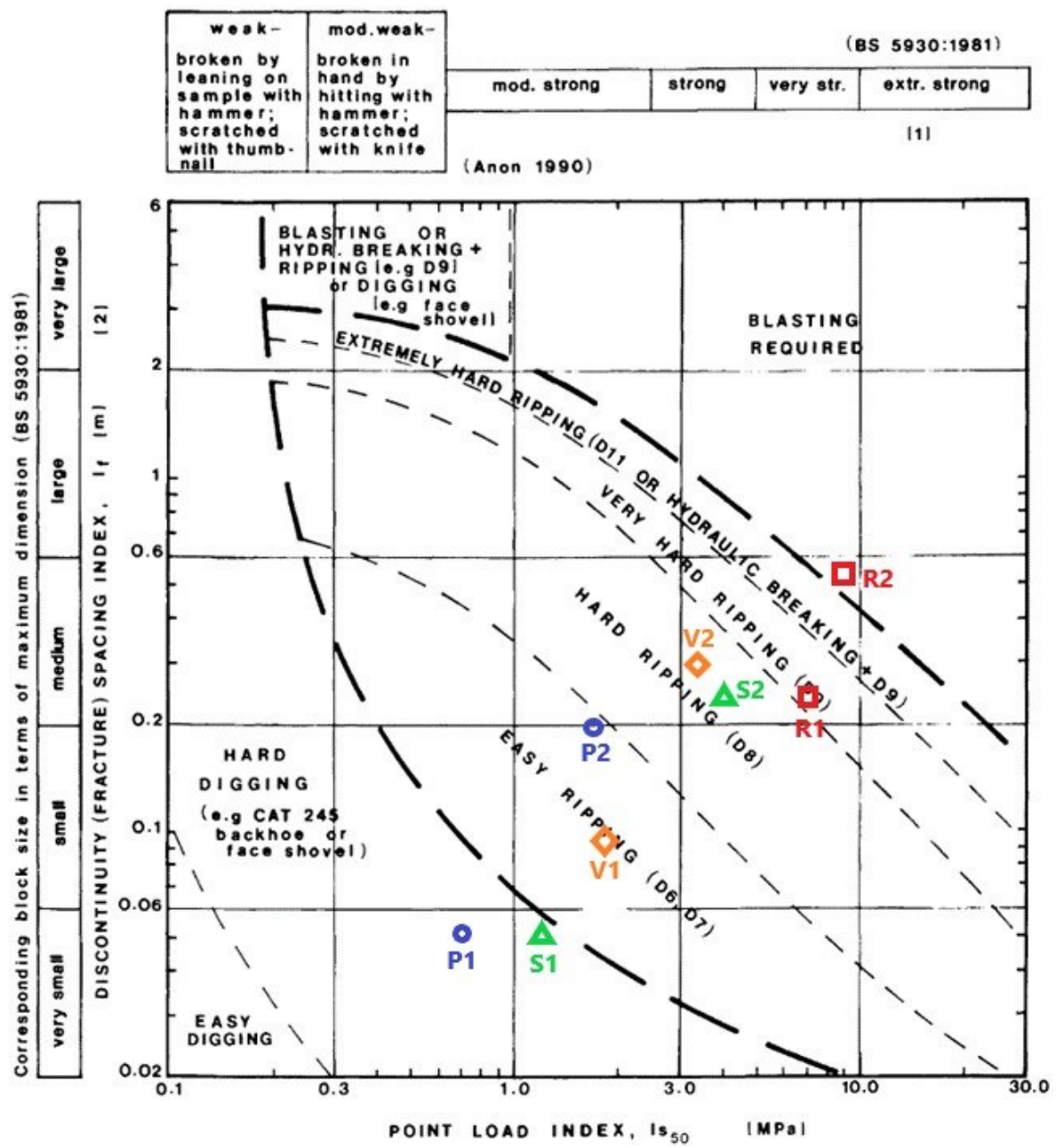

Figure 2. The chart for excavation assessing proposed by Pettifer \& Fookes (1994), with added data from the present study

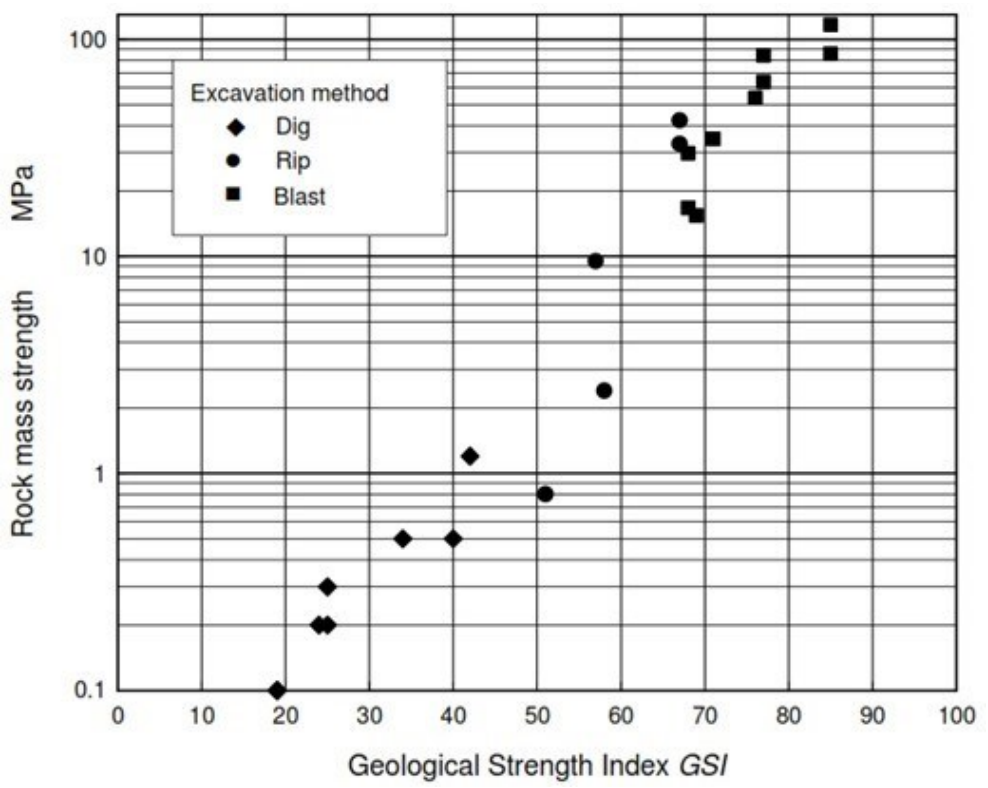

Figure 3. Plot of rock mass strength versus GSI for different excavation methods, after Abdullatif and Cruden (1983) 


\section{CAREFUL BLASTING}

Mining works must be carried out technologically, technically and organizationally in order to ensure the protection of people, natural and constructed buildings, equipment, environment, etc. The most common byproduct of blasting is damage to surrounding structures as a result of soil vibrations.

Blasting seismic waves causes mechanical movements of the soil, which represent non-stationary periodic oscillations (Figure 1). When seismic waves reach a structure, part of the energy of the ground oscillation is transferred to its foundations, so that dynamic stresses occur in some parts of the structure. At a given earthquake intensity, these stresses can exceed the ultimate strength of the material from which the structure is constructed, and permanent deformation can occur. The degree of damages thus caused depends directly on the oscillation velocity of the building and the soil particles.

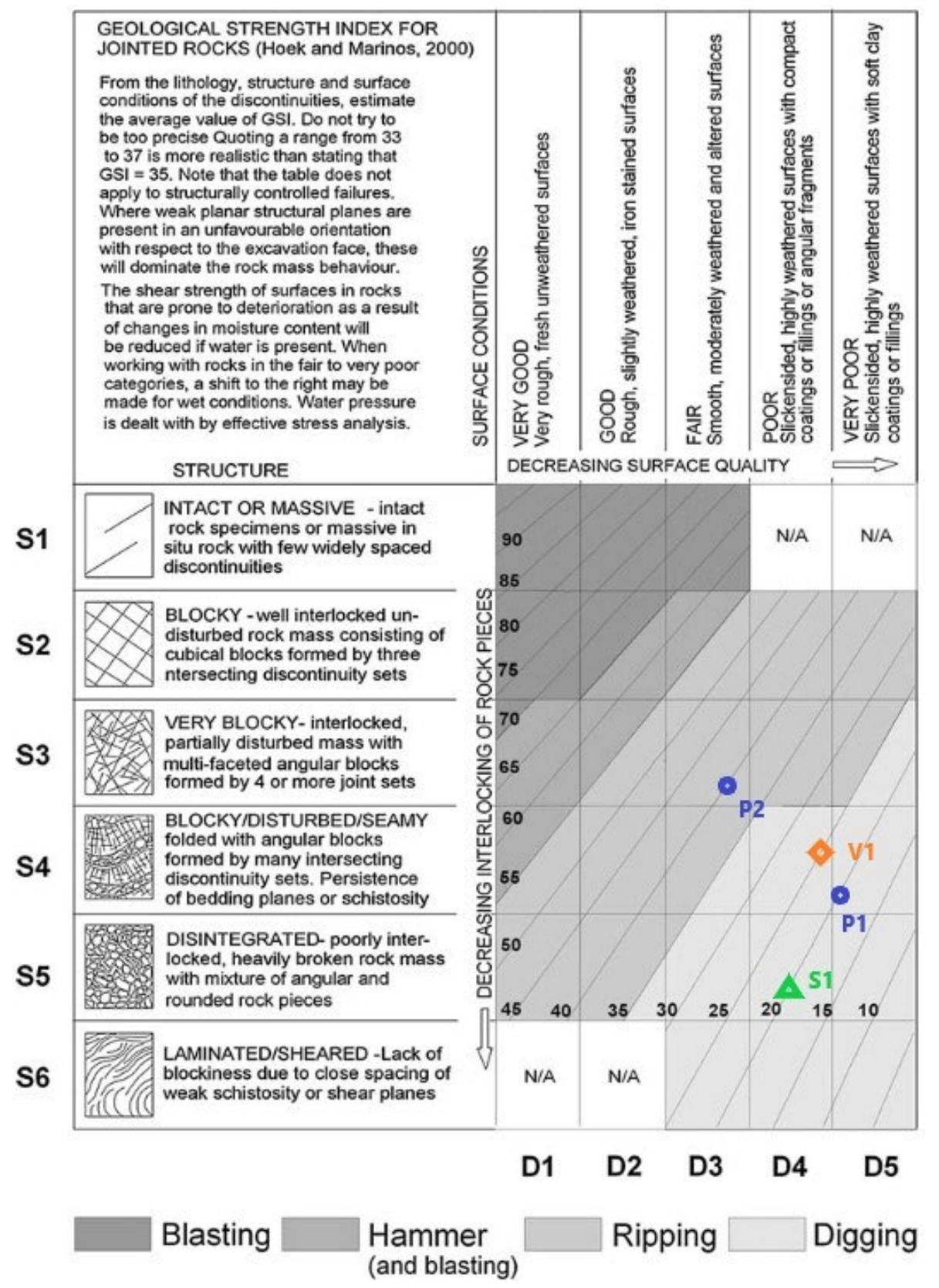

Figure 4. Classification GSI diagram for rock masses with Is 50 values below 3 MPa proposed by Tsiambaos \& Saroglou (2010), with added data from the present study

\subsection{Measuring of ground oscillations velocity during blasting}

For blasting operations that take place without adverse effects, it is necessary to perform field measurements of the ground oscillation velocity during blasting. Seismograph instruments are used to measure the magnitudes of soil oscillations. The measuring instruments are equipped with three-component geophones, which record the 
velocities of the three components of ground oscillations. This is possible because the three-component geophone consists of three geophones arranged in three spatial, mutually perpendicular axes and mechanically connected in one unit as follows:

- Two geophones placed in the horizontal plane. One in the direction of the blasting point (for registration of the longitudinal component, indicated by 1 in Figure 6). The other perpendicular to the previous one (for registration of the transversal component, indicated by 2 in Figure 6).

- A third geophone is perpendicular to the horizontal plane (to register the vertical component of the oscillations, indicated by 3 in Figure 6).

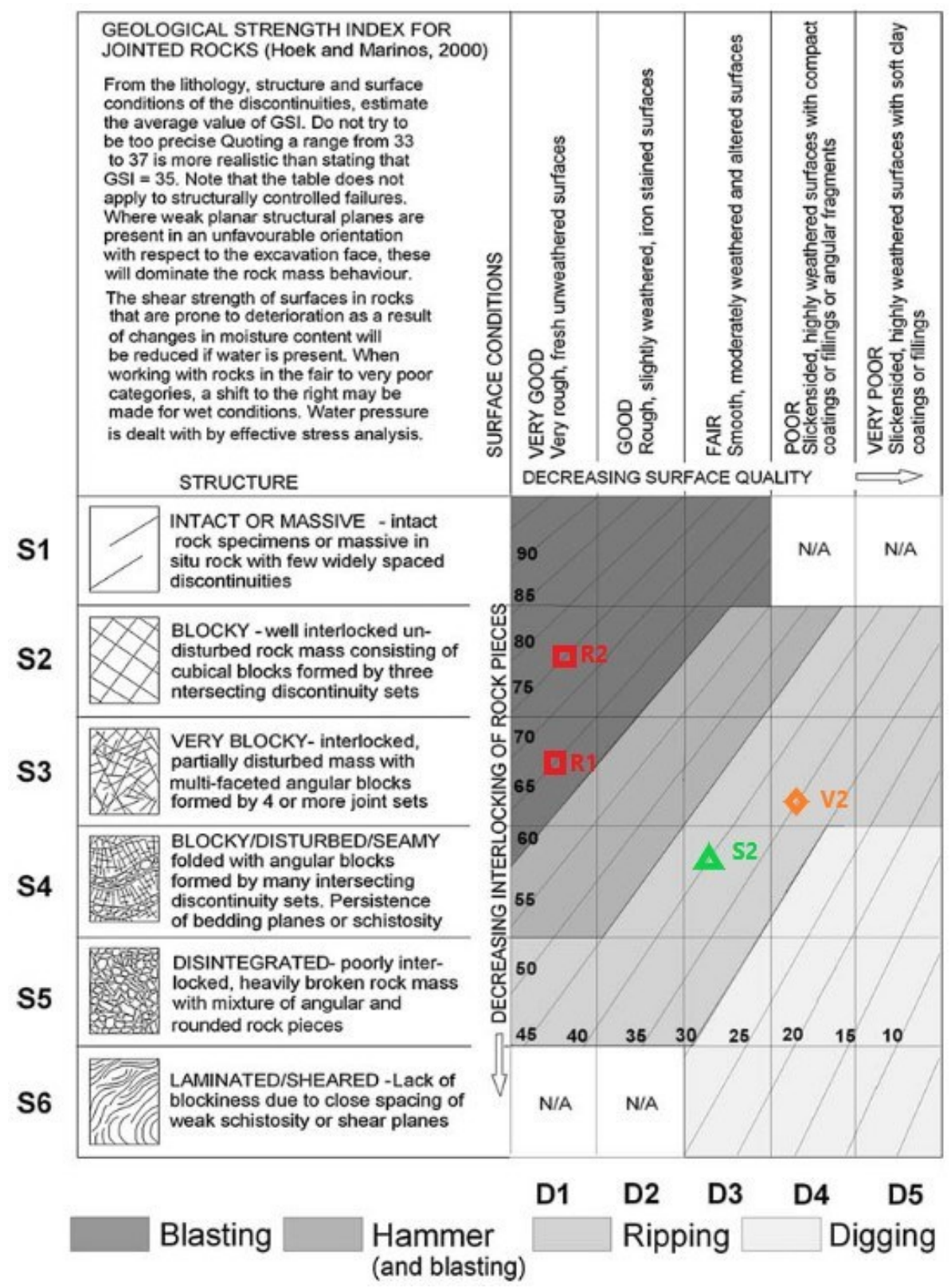

Figure 5. Classification GSI diagram for rock masses with $I_{50} \geq 3$ MPa proposed by Tsiambaos \& Saroglou (2010), with added data from the present study

After the detonation of the explosives, each geophone registers one irregular curve obtained on the seismogram. Then the velocities of the individual oscillation components are calculated $\left(\mathrm{V}_{\mathrm{L}}\right.$ is longitudinal, $\mathrm{V}_{\mathrm{T}}$ is transversal, and $V_{V}$ is the vertical component of oscillations). The resultant velocity of ground oscillations $V_{R}$ is equal to the vector sum of the velocities of the individual oscillation components (Equation 1), which are taken from the seismogram at the time of the greatest disturbance.

$$
V_{R}=\sqrt{V_{L}^{2}+V_{T}^{2}+V_{V}^{2}}
$$




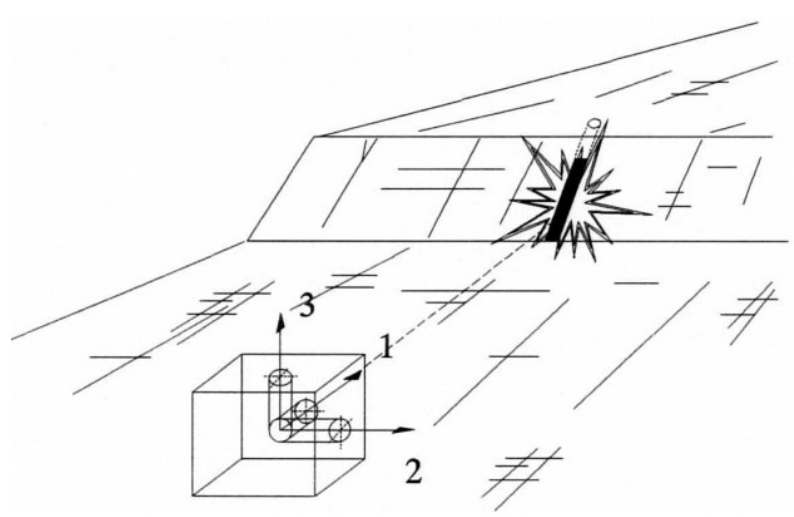

Figure 6. Orientation of geophones in relation to the blasting site (Božić 1998)

\subsection{A criterion for seismic hazard assessment in blasting}

Blasting vibrations are influenced by a number of factors, such as physical-mechanical properties and geological structure of the rock mass through which seismic waves propagate, the amount and type of explosive charge, the manner and sizes of blasting, and the distance from the blasting site. The intensity of oscillations is expressed in various measuring values such as displacement, velocity, acceleration, frequency or energy of oscillations. Which of these values best represents the intensity of the seismic effect remains an open question, so different criteria are used to assess the seismic hazard.

In Croatia, buildings are classified according to categories by standard (HRN DIN 4150-3:2011), and the permitted ground oscillation velocities are determined according to the frequency of oscillations. A graphical representation of the limit values for permissible ground oscillation values is given in Figure 7.

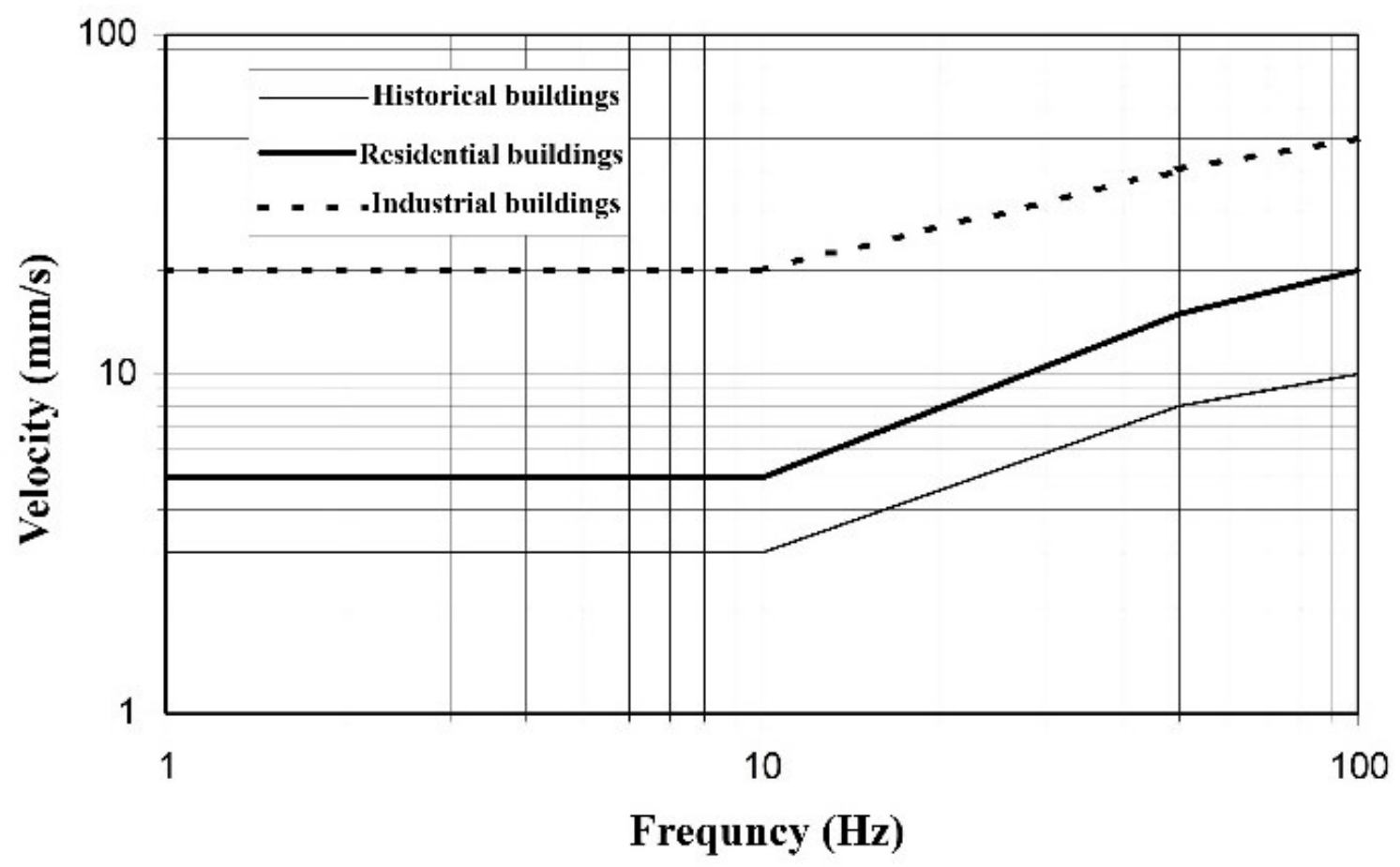

Figure 7. Diagram of limit values of permissible ground oscillation velocities (according to HRN DIN 4150-3:2011)

\section{FIELD AND LABORATORY INVESTIGATIONS}

Investigations have been carried out on four sedimentary rock sites in the karst area of Croatia, before excavation. The aim of investigations was to collect the rock mass parameters required for classification according to the methods in Chapter 2. All field investigations and laboratory testing were conducted in accordance with the International Society for Rock Mechanics suggested methods (ISRM 1981; 2007). 


\subsection{Study sites and geological settings}

According to the basic geological map of Croatia (Figure 8), the local geology of the sites is as follows:

1. Pula - the investigated area is composed of massive Cretaceous deposits, which correspond to thinly stratified limestones with rare deposits of dolomite, marl and breccia.

2. Rijeka - the location is composed of Cretaceous carbonates, which correspond to thinner or thicker layered limestones.

3. Split - the investigated area of the project is composed of massive flysch Paleogene deposits.

4. Vrbovsko - the location is composed of massive Triassic and Jurassic sediments, which corresponds to dolomites.

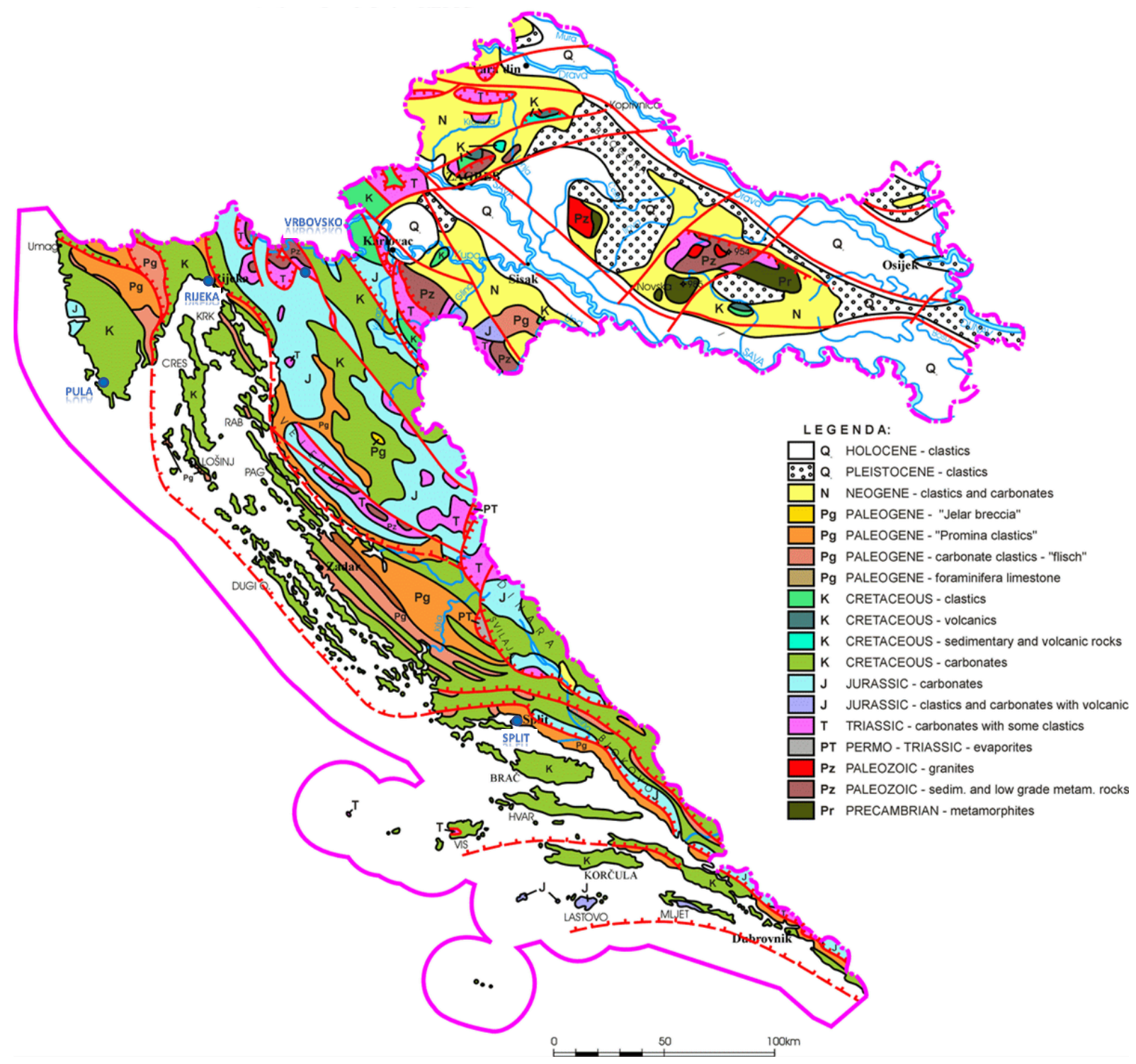

Figure 8. Basic geological map of Croatia (modified after Velić \& Velić 1992)

\subsection{Methods of field investigations and laboratory testing}

Field investigations included engineering geological mapping and exploratory core drilling. For drilling purposes, wireline equipment and a double-tube core barrel were used, which offers better recovery by isolating the rock core from the drilling fluid stream (Mayne et al. 2001). The wireline drilling equipment allows the inner tube to be uncoupled from the outer tube and raised rapidly to the surface by means of a wireline hoist. Clear water is used as drilling fluid. The field characterisation of rock masses in terms of rock type consists of determining the geological strength index (GSI) and fracture spacing index $\left(\mathrm{I}_{\mathrm{f}}\right)$ from drill core.

Laboratory tests on samples of intact rock from boreholes included compressive strength of intact rock samples $\left(\sigma_{\mathrm{ci}}\right)$ and PLTi. The uniaxial compressive strength (UCS) tests were carried out in a hydraulic press on rock 
borehole samples in the form of specimens of regular geometry (ISRM 1981; 2007). $\sigma_{\mathrm{ci}}$ was calculated by dividing the maximum load on the specimen during the test by the original cross-section area. PLT was carried out on borehole samples formed by regular and irregular rock cylindrical specimens. The tested samples required only some geometric minimums, with the indispensable requirement that the rupture of the specimen was produced by a fracture plane (or several) that contain the two points of the load application (ISRM 1985). PLT was normalized for cylindrical specimens that are $50 \mathrm{~mm}$ in diameter, obtaining the $\mathrm{Is}_{50}$.

\subsection{Practical excavations}

The results of all field investigations and laboratory testing, presented in Table 1, were used as input data for testing and comparison three existing classifications described in Chapter 2. Data was added to the chart for excavation assessing proposed by Pettifer \& Fookes (1994) (Figure 2) and classification diagrams proposed by Tsiambaos \& Saroglou (2010) (Figures 4 and 5). Assessments are shown in Table 2, and applied excavation methods at the individual studied sites are presented in the last column.

By comparing the excavation technologies used for practical excavations and assessments of the methods for prediction of the rock mass excavatability (Table 2), it is observed that Hoek \& Karzulovic method and Tsiambaos \& Saroglou method have achieved very good assessments. The assessment of both methods was incorrect only for the Split S2 site, where the rock was excavated by digging, and the assessments were that ripping is required.

Method recommended by Pettifer \& Fookes (1994) was slightly less successful. In three cases (sites R1, S2 and V1) method predicted ripping, while in one case, the excavation was carried out by blasting and in two cases by digging (Table 2).

Table 1. Results of field investigations and laboratory tests on samples of intact rock from boreholes

\begin{tabular}{|c|c|c|c|c|c|c|c|}
\hline SITE & ROCK TYPE & $\begin{array}{c}\text { DATA } \\
\text { ID }\end{array}$ & $\begin{array}{c}\sigma_{\mathrm{ci}}(\mathrm{MPa}) \\
\text { AVERAGE }\end{array}$ & $\begin{array}{c}\sigma_{\mathrm{cm}}(\mathrm{MPa}) \\
\text { AVERAGE }\end{array}$ & $\begin{array}{c}\text { Is50 }(\mathrm{MPa}) \\
\text { AVERAGE }\end{array}$ & $\begin{array}{c}\text { GSI } \\
\text { AVERAGE }\end{array}$ & $\begin{array}{c}\mathrm{I}_{\mathrm{f}}(\mathrm{m}) \\
\text { AVERAGE }\end{array}$ \\
\hline \multirow{2}{*}{ Pula } & \multirow{2}{*}{ Limestone } & P1 & 11.5 & 0.5 & 0.64 & 20 & 0.05 \\
\hline & & $\mathrm{P} 2$ & 35.5 & 3 & 1.85 & 40 & 0.2 \\
\hline \multirow{2}{*}{ Rijeka } & \multirow{2}{*}{ Limestone } & R1 & 143 & 15 & 7.16 & 65 & 0.25 \\
\hline & & $\mathrm{R} 2$ & 178 & 20 & 9.12 & 75 & 0.50 \\
\hline \multirow{2}{*}{ Split } & \multirow{2}{*}{ Flysch } & $\mathrm{S} 1$ & 16 & 0.5 & 1.21 & 20 & 0.01 \\
\hline & & $\mathrm{S} 2$ & 41 & 3 & 4.06 & 40 & 0.25 \\
\hline \multirow{2}{*}{ Vrbovsko } & \multirow{2}{*}{ Dolomite } & V1 & 42 & 2 & 1.91 & 25 & 0.1 \\
\hline & & $\mathrm{V} 2$ & 74.5 & 4 & 3.39 & 35 & 0.3 \\
\hline
\end{tabular}

Table 2. Assessments of existing classifications and selected practical excavation

\begin{tabular}{|c|c|c|c|c|c|c|}
\hline SITE & $\begin{array}{l}\text { ROCK } \\
\text { TYPE }\end{array}$ & $\begin{array}{l}\text { DATA } \\
\text { ID }\end{array}$ & $\begin{array}{l}\text { PETTIFER AND } \\
\text { FOOKES (1994) }\end{array}$ & $\begin{array}{l}\text { HOEK AND } \\
\text { KARZULOVIC } \\
(2000)\end{array}$ & $\begin{array}{c}\text { TSIAMBAOS } \\
\text { AND SAROGLOU } \\
(2010)\end{array}$ & $\begin{array}{l}\text { PRACTICAL } \\
\text { EXCAVATION } \\
\text { TECHNOLOGY }\end{array}$ \\
\hline \multirow{2}{*}{ Pula } & \multirow{2}{*}{ Limestone } & $\mathrm{P} 1$ & Hard Digging & Dig & Digging & Digging \\
\hline & & $\mathrm{P} 2$ & Easy Ripping & Rip & Ripping & Ripping \\
\hline \multirow{2}{*}{ Rijeka } & \multirow{2}{*}{ Limestone } & $\mathrm{R} 1$ & Very Hard Ripping & Blast & Blasting & Blasting \\
\hline & & $\mathrm{R} 2$ & Blasting Required & Blast & Blasting & Blasting \\
\hline \multirow{2}{*}{ Split } & \multirow{2}{*}{ Flysch } & S1 & Hard Digging & Dig & Digging & Digging \\
\hline & & $\mathrm{S} 2$ & Hard Ripping & Rip & Ripping & Digging \\
\hline \multirow{2}{*}{ Vrbovsko } & \multirow{2}{*}{ Dolomite } & V1 & Easy Ripping & Dig & Digging & Digging \\
\hline & & $\mathrm{V} 2$ & Hard Ripping & Rip & Ripping & Ripping \\
\hline
\end{tabular}

On study site in Rijeka blasting could not be avoided, because there is no mechanical technology for excavation rock mass so good quality. For the purpose of constructing a building in Rijeka, a construction pit had to be excavated with blasting works. Therefore, it was necessary to design and perform careful blasting in order to minimize the impact of rock mass excavation on the environment.

In order to carry out special blasting operations in the urban area, without adverse consequences, it was necessary to make previous investigations. Therefore, field measurements of the ground vibrations during trial blasting were performed with Instantel Minimate Plus seismograph, as described in Chapter 3.1., next to the residential building closest to the blasting site. 
During the first trial blasting, with three holes $6 \mathrm{~m}$ deep and $89 \mathrm{~mm}$ in diameter, the maximum weight of bulk explosive charge in one interval was 18.5 kilograms. Diagram obtained using a Blastware 10.74 software (Instantel 2015) in Figure 9a shows that, during this blasting, the peak particle velocities (PPV) of the longitudinal component have crossed the allowable values line for residential buildings, with dominant frequency values of about $15 \mathrm{~Hz}$.

Therefore, the oscillation velocities should be reduced for the next trial blasting. Various methods and techniques for reducing soil vibration during blasting have been considered to solve the problem, such as reducing the depth of blast holes, increasing the activation interval between blast holes or blast hole rows, reduction of stemming length, etc. However, reducing the explosive charge weight in one interval probably most effects on the soil oscillation velocities.

Using Equation 2 (Langefors et al. 1957), the optimal explosive charge weight (CW) in one interval was calculated ( $\mathrm{D}$ is the distance from the blasting site, and $\mathrm{K}$ is site constant). During the second trial blasting the maximum weight of bulk explosive charge in one interval was 16 kilograms. The optimal explosive charge was achieved by reducing the blast hole diameter from $89 \mathrm{~mm}$ to $64 \mathrm{~mm}$. The depth of blast holes remained $6 \mathrm{~m}$. When observing the second trial blast, the peak particle velocities (PPV) dropped below the maximum permitted values, as a result of reduction explosive charge weight (Figure 9b).

$$
\mathrm{CW}=\left(\left(\frac{\mathrm{PPV}}{\mathrm{K}}\right) \cdot \mathrm{D}^{3 / 4}\right)^{2}
$$

a)

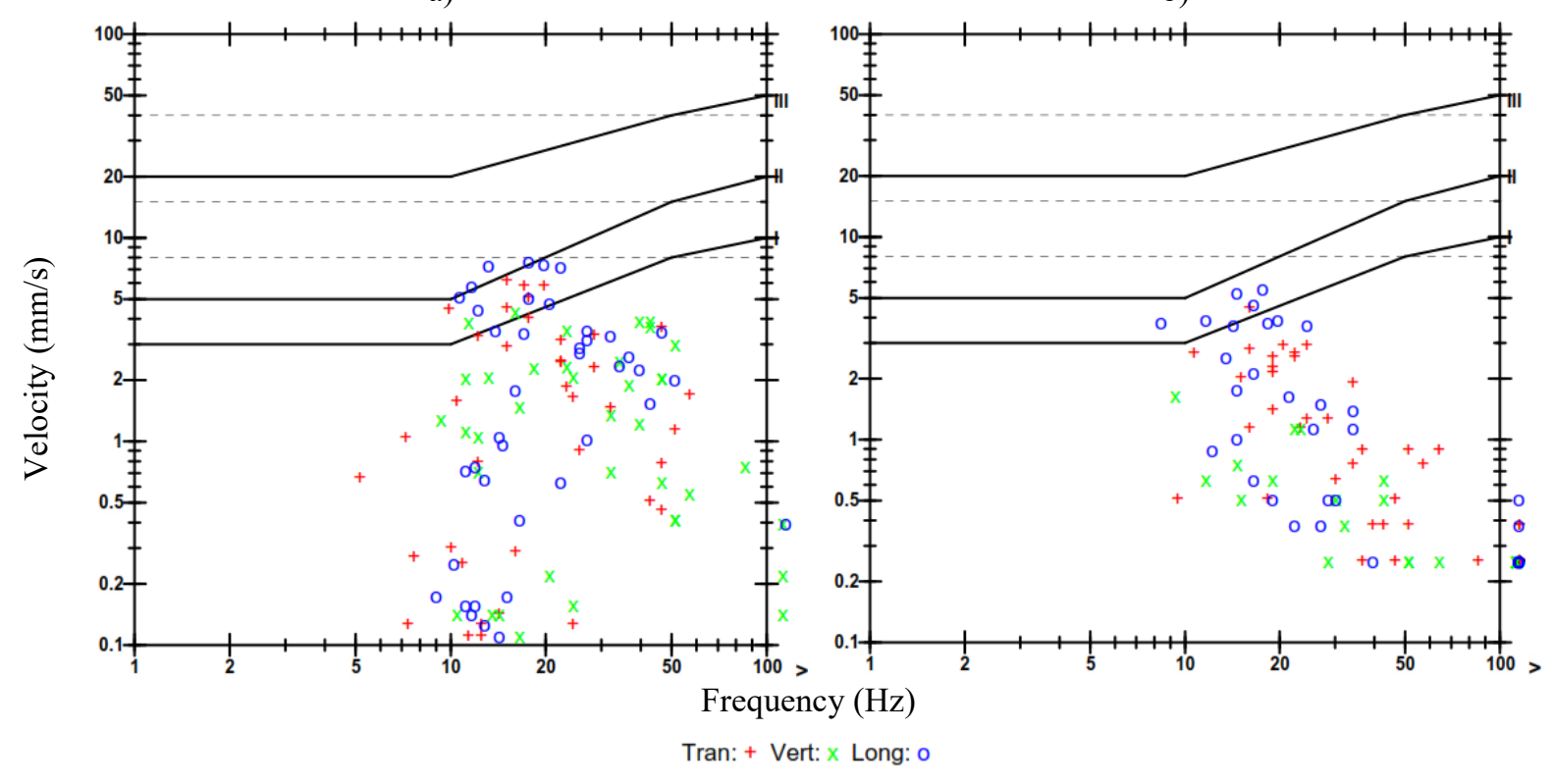

I - Historical buildings; II - Residential buildings; III - Industrial buildings

Figure 7. Results of measuring the soil oscillation velocities during blasting at a study site in Rijeka: a) $1^{\text {st }}$ trial blasting; b) $2^{\text {nd }}$ trial blasting

\section{CONCLUSIONS}

When excavating rock mass, there are environmental impacts associated with the blasting. Adverse blasting effects include noise, fly-rock, dust and chemical contamination. The most significant effect is ground vibration, and it is important to be able to control them. Control is performed by field measurements of vibration intensity. The results obtained are used to produce quality blasting projects, which must comply with the prescribed standards for seismic hazard assessment in blasting.

Whenever possible, or when the rock mass characteristics allow it, it is recommended to use a mechanical excavation that is less harmful to the environment. To predict the rock mass excavatability, different classification methods are available, and three most commonly used were tested. The results show that Petiffer \& Fokes method is less reliable than other methods. Therefore, it is recommended to use Hoek \& Karzulovic method or Tsiambaos \& Saroglou method for future assessments of rock mass excavatability.

If assessments indicate that it is not possible to avoid excavation by blasting, the controlled careful blasting techniques should be applied in order to minimize the impact ground vibration on the environment. Various 
techniques for reducing soil vibration during blasting are known in the mining profession, but it has been shown that using the optimal explosive charge weight in one interval is a good and simple solution. By reducing the blast hole diameter, the consumption of explosives decreases and the optimal level of charge weight is reached.

\section{ACKNOWLEDGMENTS}

The authors are very grateful to the companies SPP d.o.o. and Geomin d.o.o. for providing logistic support, field and laboratory work and practical excavations. The comments and corrections made by Prof. Stjepan Strelec and Assoc. Prof. Petar Hrženjak has improved the paper considerably and are duly acknowledged.

\section{REFERENCES}

Abdullatif OM, Cruden DM (1983) The relationship between rock mass quality and ease of excavation. Bull Eng Geol Environ 28:183-187

Ainalis D, Kaufmann O, Tshibangu JP, Verlinden O, Kouroussis G (2017) Modelling the Source of Blasting for the Numerical Simulation of Blast-Induced Ground Vibrations: A Review. Rock Mech Rock Eng. doi:10.1007/s00603-016-1101-2

Božić B (1998) Miniranje u rudarstvu, graditeljstvu i geotehnici, Sveučilišni udžbenik, Geotehnički fakultet, Varaždin, Hrvatska

Broch E, Franklin JA (1972) The Point Load Strength Test. Int Journal Rock Mech Min Sci 9:669-697

Caterpillar Inc. (2015) Caterpillar performance handbook. Edition 45, Caterpillar Inc., Preoria, Illinois, USA

Church HK (1981) Excavation handbook. McGraw-Hill Inc., New York, USA

Dhekne PY (2015) Environmental Impacts of Rock Blasting and Their Mitigation. International Journal of Chemical, Environmental \& Biological Sciences (IJCEBS) 3(1):46-50

Franklin JA, Broch E, Walton G (1971) Logging the mechanical character of rock. Trans. Institution of Mining and Metallurgy 80:A1-A9

Hoek E, Marinos P, Benissi M (1998) Applicability of the Geological Strength Index classification for very weak and sheared rock masses. The case of the Athens Schist Formation. Bull Eng Geol Environ 57:151-160

Hoek E, Karzulovic A (2000) Rock mass properties for surface mines. In: W.A. Hustralid, M.K. McCarter and D.J.A. van Zyl, eds. Slope Stability in Surface Mining. Littleton, CO: Society for Mining, Metallurgical and Exploration (SME) 59-70

HRN DIN 4150-3:2011 (2011) Vibrations in buildings - Part 3: Effect on structures (DIN 4150-3:1999). Croatian Standards Institute, Zagreb

Instantel Inc. (2015) Blastware Operator Manual. Ottawa, Ontario, Canada

International Society for Rock Mechanics ISRM (1981) Rock characterization, testing and monitoring. In:

Brown ET (ed) ISRM suggested methods. Pergamon Press, Oxford

International Society for Rock Mechanics ISRM (1985) Point load test, suggested method for determining point load strength. Int J Rock Mech Min Sci and Geomech Abstr 22:51-60

International Society for Rock Mechanics ISRM (2007) The Blue Book: "The Complete ISRM Suggested

Methods for Rock Characterization, Testing and Monitoring:1974-2006", Edited by R. Ulusay and J.A. Hudson

Langefors U, Kihlstrom B, Westerberg H (1957) Ground Vibrations in Blasting. Water Power, New York

Mayne PW, Christopher BR, DeJong J (2001) Manual on Subsurface Investigations. National Highway Institute, Publication No. FHWA NHI-01-031, Washington, USA

Mesec J, Težak D, Jug J (2018) Reducing the adverse effects of blasting on the cave ecosystem near the future exploitation field Gradusa. Rudarsko-geološko-naftni zbornik 33(4):45-54. doi:10.17794/rgn.2018.4.4

Pettifer GS, Fookes PG (1994) A revision of the graphical method for assessing the excavability of rock. Q J Eng Geol. Hydrogeol 27:145-164

Tomberg T, Toomik A (1999) Environmental Impact of Mine Blasting. Environment Technology. doi:10.17770/etr1999vol1.1872

Tsiambaos G, Saroglou H (2010) Excavatability assessment of rock masses using the Geological Strength Index (GSI). Bull Eng Geol Environ 69:13-27

Velić I, Velić J (1992) Cover for Geologia Croatica, Vol 45

Weaver, JM (1975) Geological factors significant in the assessment of rippability. Civil Engineering in South Africa, Siviele Ingenieurswese, 17(12):313-316 